\title{
UTILIZATION OF STONEDUST WITH PLASTIC WASTE FOR IMPROVING THE SUBGRADE IN HIGHWAY PAVEMENT CONSTRUCTION
}

\author{
Kanaka Prava Mahali ${ }^{1}$, A.K. Sinha ${ }^{2}$ \\ ${ }^{1}$ Postgraduate Student, Civil Engg. Department, NIT, Jamshedpur \\ ${ }^{2}$ Associate Professor, Civil Engg. Department, NIT, Jamshedpur
}

\begin{abstract}
Stone dust is a kind of waste material that is generated from the stone crushing industry which is abundantly available to the extent of 200 million tonnes per annum, that has landfill disposal problems and health and environmental hazards. This study cover on utilization of stone dust reinforced with PET strips(polyethylene terephthalete)improving the sub grade. Now a day's both stone dust and plastic water bottles are creating environmental disposal problem as well as health problem. Therefore utilization of these waste material in proper manner is creating challenge to society. PET strips obtained from waste plastic water bottle, were mixed randomly with stone dust. A series of California bearing ratio (CBR) tests were carried out on reinforced stone dust. Three different sizes of PET strips were used in this study. The effect of strips content $(0.25 \%$ to $2 \%)$ and length on the CBR value of reinforced stonedust were investigated.
\end{abstract}

Addition of PET strips with in stone dust with appropriate amount improved the strength of sub grade. This reinforcing material can used as sub grade material in constructing the rural road over saturated clay. This method is a environmental friendly and reduce the disposal problem.

Keywords: Stone dust, polyethylene terephthalete, CBR value.

\section{INTRODUCTION}

Every year a large part of industrial waste materials is disposed of in landfills or arbitrarily discharged to the environment. Therefore, researchers are waste material in engineering field.

Due to high demand for rubble and aggregates for construction purposes, rubble quarries \& aggregates crushers are very common. Out of the different quarry wastes, stone dust is one which is produced in abundance. About $20-25 \%$ of the total production in each crusher unit is left out as the waste material as stone dust . Utilization of this waste material is possible through geotechnical applications like embankment, backfill material, sub-base material \& the like.

Similarly using of plastic products such as polythene bags, bottles containers \& packing strips etc. is increasing day by day. The disposal of the plastic wastes without causing any ecological hazards has become a real challenge to the present society.

The general survey show that 1500 bottles are dumped as garbage every second. PET is reported as one of the most abundant plastics in solid urban waste( De mello et al.,2009).On an average, an Indian uses one kilogram( $\mathrm{kg}$ ) of plastics per year \& the world annual average is an alarming $18 \mathrm{~kg}$. It is estimated that approximately $4-5 \%$ post consumer plastic waste by weight of Municipal solid waste (MSW) is generated in india. As per data available on MSW , approximately, 4000-5000 tonnes per day post consumer plastic wastes are generated. Hence there needs to be concerted efforts in the reuse of plastic waste from water bottles \& this study is in this direction.

This study investigate the effect of stone dust reinforced with PET strips by conducting a series of CBR tests. Three different sizes of PET Strips as length of $10 \mathrm{~mm}, 20 \mathrm{~mm}$, and $30 \mathrm{~mm}$ of width $10 \mathrm{~mm}$ were used.

The plastic strips were mixed as $0.25 \%$ to $2 \%$ with dry weight of stone dust.

\section{LITERATURE REVIEW}

In the recent years several researchers are trying to develop solutions for the reuse of different types of wastes generated which has become one of the major challenges for the environmental issues in many countries. Several researchers presented technique of using discrete fibers to enhance the strength of soil.

Most of them used different types of fibers as reinforced materials and the experimental result showed that the fiber reinforced soil is a potential composite material. The tests were carried out with different types of fibers in different proportions and due to the effect of fiber, improving the 
strength and stability of soil were identified. Some of the research work conducted by earlier researchers, has been described below.

Gray and Ohashi(1983) conducted a series of direct shear tests on a dry sand reinforced with different types of fibers. Both natural \& synthetic fibers plus metal wires was tested. Experimental behavior was compared with theoretical predictions based on a force equilibrium model of a fiber reinforced sand. They concluded that inclusion of fiber, behave as ideally extensible. Shear strength increases are directly proportional to fiber area ratios, fiber content, fiber stiffness. Shear strength increases were maximum for fiber orientations of $60^{\circ}$ with respect to the shear surface. Shear strength increases as a result of fiber reinforcement were approximately the same for loose \& dense sand, respectively.

Gray and Al-Refeai(1986) carried out a series of triaxial compression test on dry sand reinforced with continuous, oriented fabric layers and also with randomly distributed discrete fibers. The influence of various test parameters such as amount of reinforcement, confining stress, inclusion modulus \& surface friction were investigated. Test results showed that both types of reinforcement systems increased strength \& modified the stress-deformation behavior of sand in a significant manner. Continuous, oriented fabric inclusions markedly increases the ultimate strength, also increased the axial strain at failure $\&$ in most cases limited reductions in post-peak loss of strength.

Maher and Gray(1990) carried out triaxial compression tests on sand reinforced with discrete, randomly distributed fibers and observed the influence of various fibre properties on soil behavior. They found that failure surfaces in a triaxial compression tests of randomly distributed fiberreinforced sand are planner \& oriented in the same manner as predicted by the Mohr-Coulomb theory, $\left(45^{\circ}+\phi / 2\right)$.

Maher and Ho(1994) carried out unconfined compressive strength, splitting-tension ,three point-bending and hydraulic-conductivity tests on kaolinite soil reinforced with polypropylene fibre at different water content and evaluated the mechanical properties of the composite soil. They observed that inclusion of fibers had a significant influence on the mechanical properties of kaolinite clay. Inclusion of fibers increased the peak compressive strength and ductility of kaolinite clay, with the increase being more pronounced at lower-composite water contents.

Nilo Cesar Consoli(2002),(2003), (2004) showed that the fiber reinforced soil is a potential composite material which can be advantageously employed in improving the structural behavior of soils. The tests were carried with different types of fibers in different proportions and the effects of fiber in improving strength and stability of soil were identified.

\section{MATERIAL USED FOR THE STUDY}

Stone dust. In this study, a type of stone dust collected from nearby crusher, Jamshedpur was used.

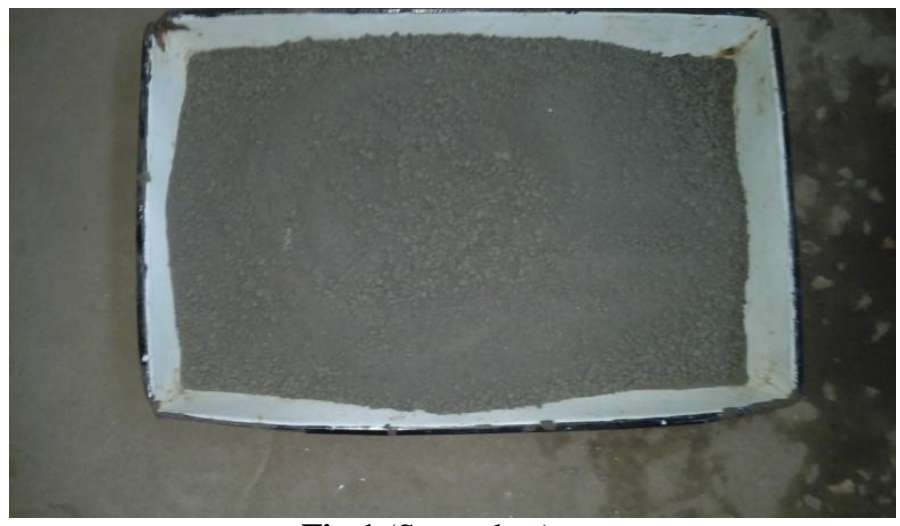

Fig.1 (Stone dust)

The properties of stone dust are given below.

(i) Grain size : -

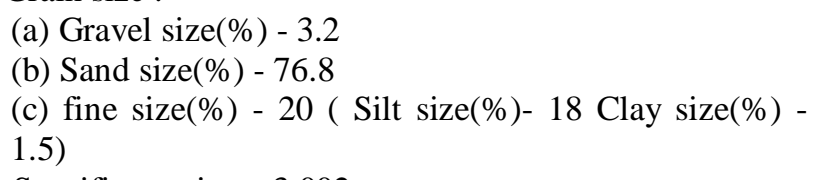

(ii) Specific gravity: - 3.002

(iii) Liquid limit - 20\% Plastic limit -NP

(iv) Compaction characteristics: OMC $-9.78 \% \mathrm{MDD}-2.12$ $\mathrm{gm} / \mathrm{cc}$

(v) $\mathrm{C}_{\mathrm{u}}=10 \& \mathrm{Cc}=0.63$

(vi) Classification of stone dust: SM

Plastic waste. For this study waste plastic water bottles were used as PET strips (polyethene terephthalete) collected from a rag picker Jamshedpur, Jharkhand. The PET strips were cut in different sizes as a length of $10 \mathrm{~mm}, 20 \mathrm{~mm}$, and $30 \mathrm{~mm}$ having a width of $10 \mathrm{~mm}$. The stone dust mixed with PET strips in varying percentage $(0.25 \%$ to $2 \%)$ by dry weight of stone dust.

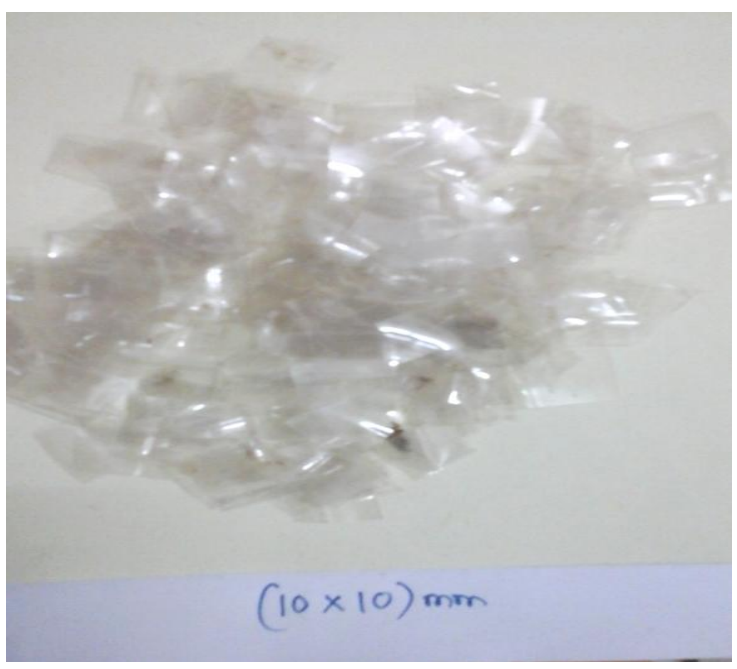

$(10 X 10) \mathrm{mm}$ 


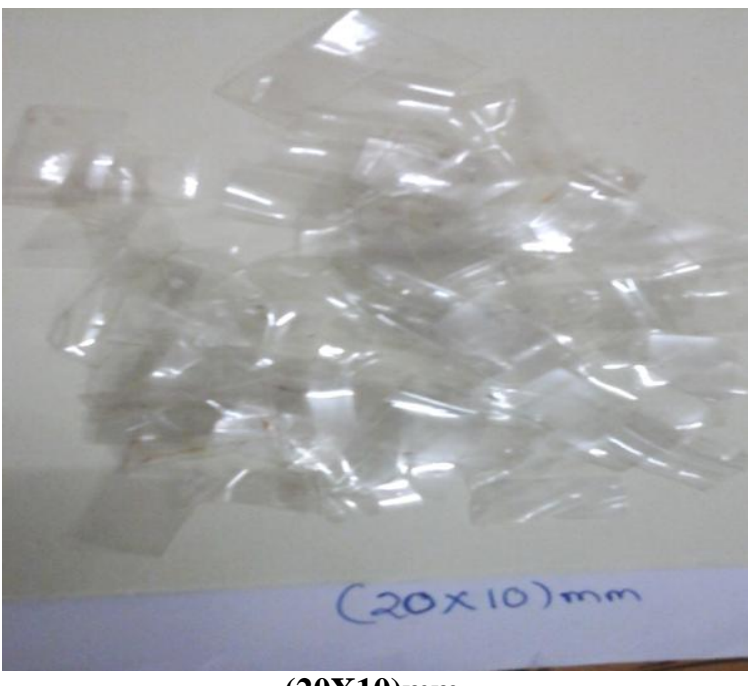

(20X10)mm

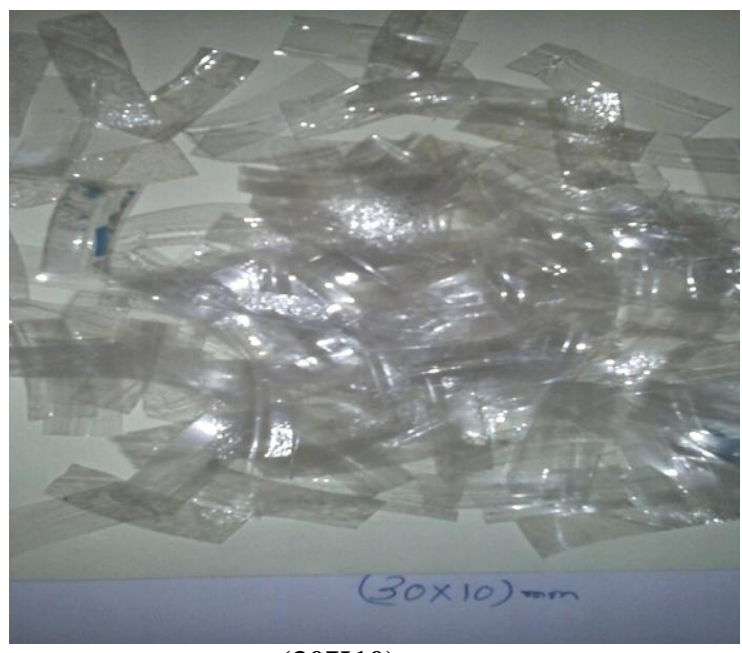

(30X10) mm
Table-1 (Properties of PET strips)

\begin{tabular}{|l|l|l|l|l|}
\hline S No. & Test & $\begin{array}{l}\text { Test } \\
\text { Method }\end{array}$ & $\begin{array}{l}\text { Results } \\
\text { obtained }\end{array}$ & Unit \\
\hline 01 & $\begin{array}{l}\text { Tensile } \\
\text { Strength }\end{array}$ & $\begin{array}{l}\text { ASTM D } \\
638\end{array}$ & 184.80 & $\mathrm{~N} / \mathrm{mm}^{2}$ \\
\hline 02 & Density & $\begin{array}{l}\text { ASTM D } \\
792\end{array}$ & 1.38 & $\mathrm{~g} / \mathrm{cc}$ \\
\hline
\end{tabular}

\section{TESTS FOR THE PRESENT STUDY}

To study the reinforcing effects of randomly mixed PET bottle strips, the following tests were done on each mix.

\subsection{Standard Proctor Test}

Standard proctor test was carried out to determine optimum moisture content and maximum dry density of the reinforced stone dust sample with plastics.

\subsection{Laboratory CBR Test}

Laboratory CBR tests were carried out to determine CBR values of the soil with plastics as per IS-2720( PART-16), 1979. CBR tests of stone dust were performed at water content of omc of the wet side of optimum moisture content of stone dust.

The stone dust was randomly mixed with different percentage of PET strips .The mix specification are as under.

SP0- Stone dust with 0\% PET strips.

SP1- Stone dust with $0.25 \%$ PET strips.

SP2-Stonedust with $0.5 \%$ PET strips

SP3- Stone dust with $1 \%$ PET strips

SP4- Stone dust with 2\% PET strips

Fig.2 Different sizes of PET strips

\section{RESULT AND DISCUSSION}

The test results are summarized in the table2.

Table-2

\begin{tabular}{|l|l|l|l|l|l|}
\hline Sl.no & Aspect ratio & Mix & OMC in \% & MDD in gm/cc & CBR (\%) \\
\hline 1 & U.R & SP0 & 9.78 & 2.12 & 17.03 \\
\hline 2 & 1 & SP1 & 9.53 & 2.13 & 30.31 \\
\hline 3 & 1 & SP2 & 9.35 & 2.15 & 35.44 \\
\hline 4 & 1 & SP3 & 9.60 & 2.16 & 37.88 \\
\hline 5 & 1 & SP4 & 9.30 & 2.18 & 43.07 \\
\hline 6 & 2 & SP1 & 9.28 & 2.13 & 31.63 \\
\hline 7 & 2 & SP2 & 8.75 & 2.15 & 33.90 \\
\hline 8 & 2 & SP3 & 8.98 & 2.17 & 41.85 \\
\hline 9 & 2 & SP4 & 9.20 & 2.19 & 46.22 \\
\hline 10 & 3 & SP1 & 9.6 & 2.14 & 33.09 \\
\hline 11 & 3 & SP2 & 8.95 & 2.17 & 37.88 \\
\hline 12 & 3 & SP3 & 8.70 & 2.19 & 43.60 \\
\hline 13 & 3 & SP4 & 8.90 & 2.21 & 47.68 \\
\hline
\end{tabular}




\section{compaction curve of stone dust with PET strips content}

(0.25\% to $2 \%) A R=1$

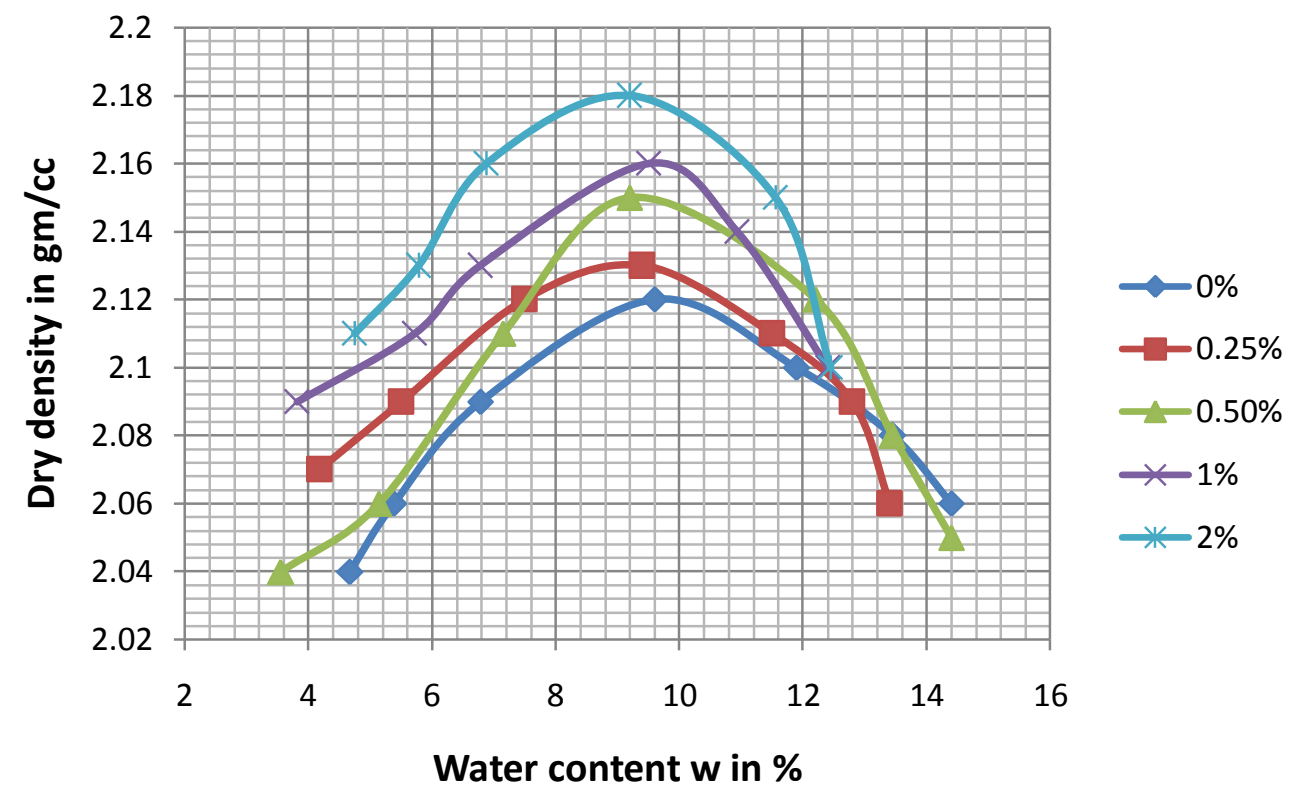

Fig-3 compaction curve of stone dust with PET strips content( $(0.25 \%$ to $2 \%) \mathrm{AR}=1$

\section{compaction curve of stonedust with PET strips content $(0.25 \%$ to $2 \%) A R=2$}

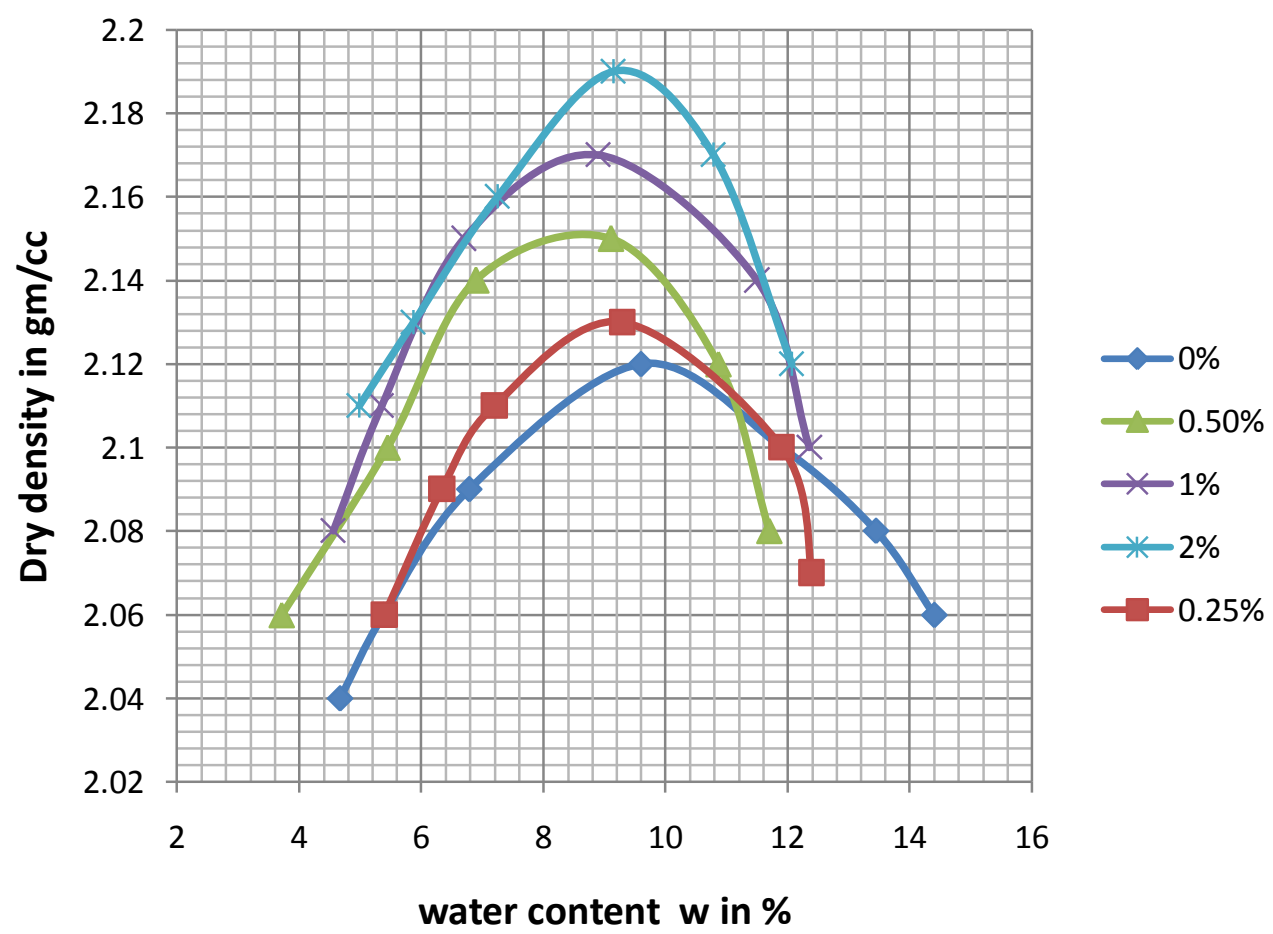

Fig-4 compaction curve of stone dust with PET strips content $(0.25 \%$ to $2 \%) \mathrm{AR}=2$ 


\section{compaction curve of stone dust with PET strips content} $(0.25 \%$ to $5 \%) A R=3$

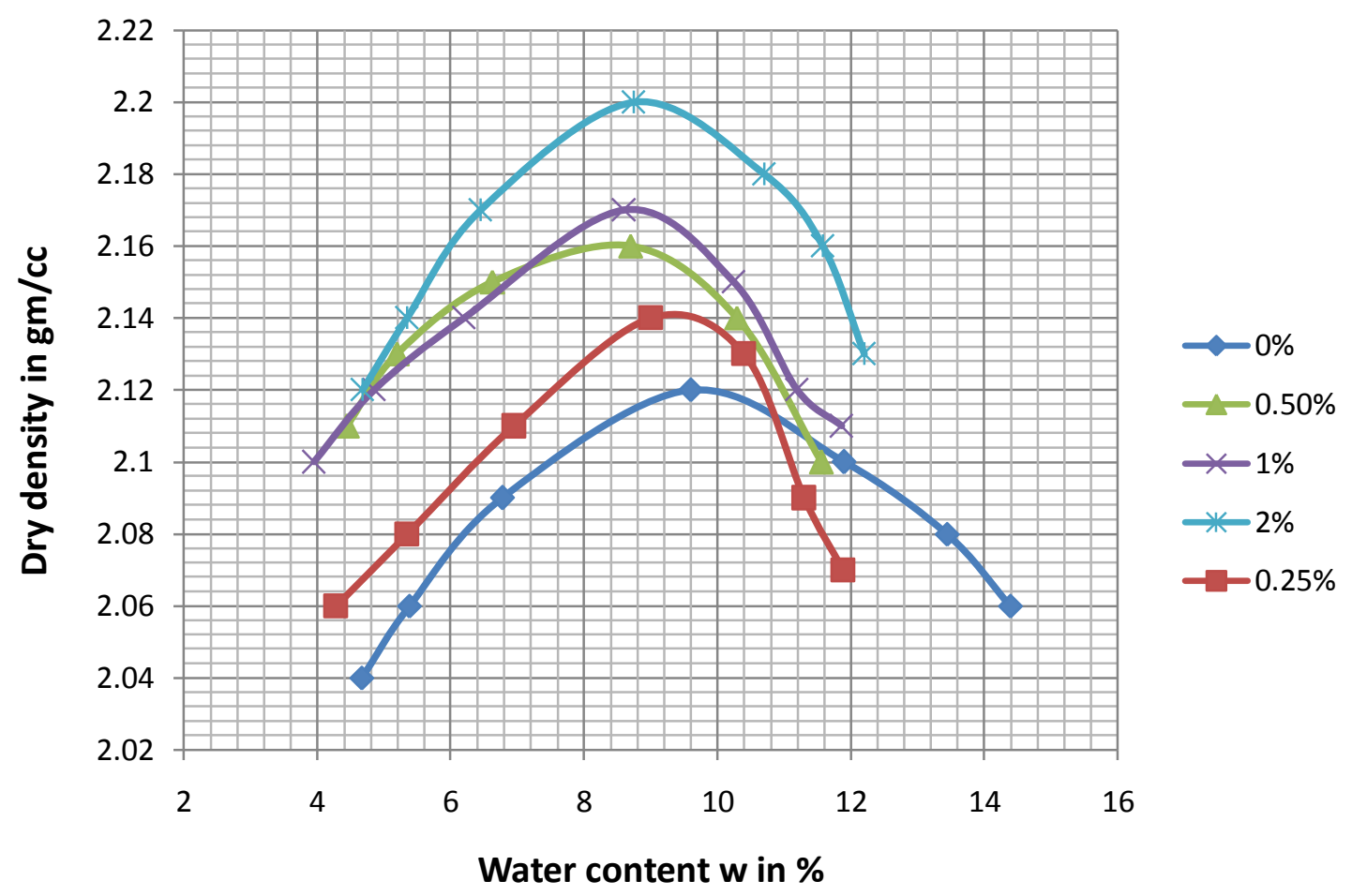

Fig-5 compaction curve of stone dust with PET trips content $(0.25 \%$ to $2 \%) \mathrm{AR}=3$

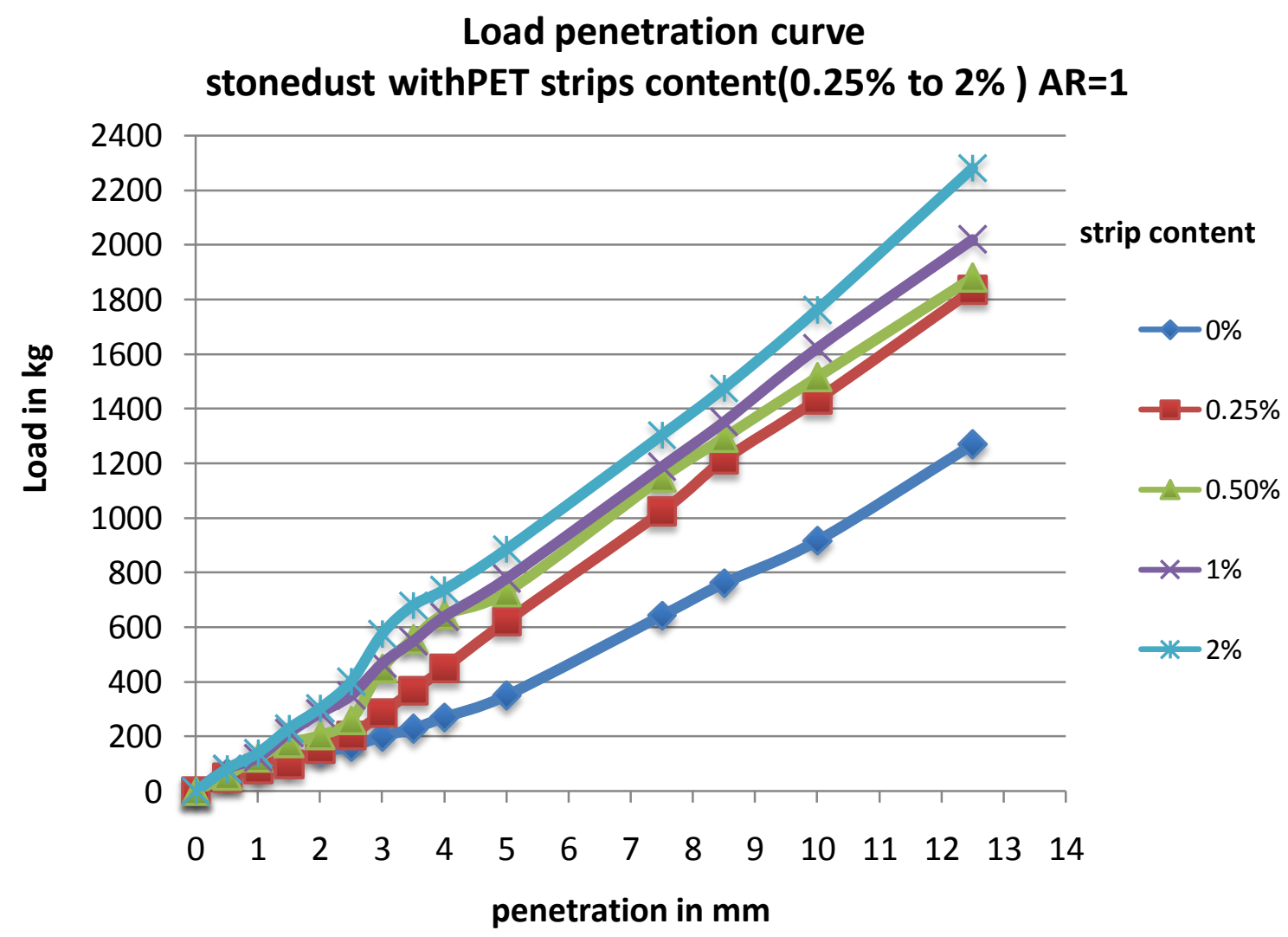

Fig-6 Load Penetration curve of stone dust with PET strips content $(0.25 \%$ to $2 \%) \mathrm{AR}=1$ 


\section{Load penetration curve stonedust withPET strips content $(0.25 \%$ to $2 \%) A R=2$}

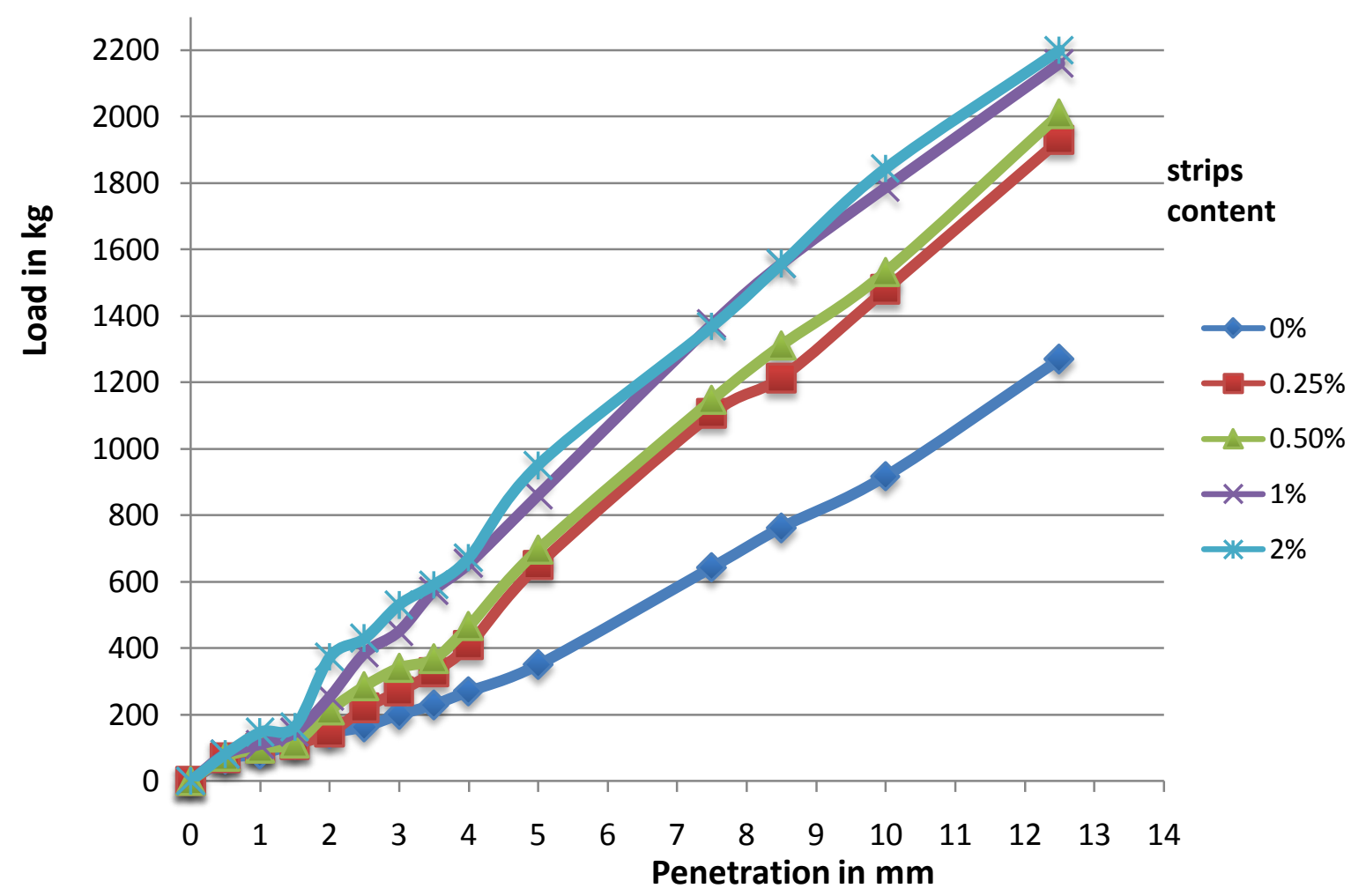

Fig-7 Load Penetration curve of stone dust with PET strips content $(0.25 \%$ to $2 \%) \mathrm{AR}=2$

Load penetration curve stone dust withPET strips content( $0.25 \%$ to $2 \%) A R=3$

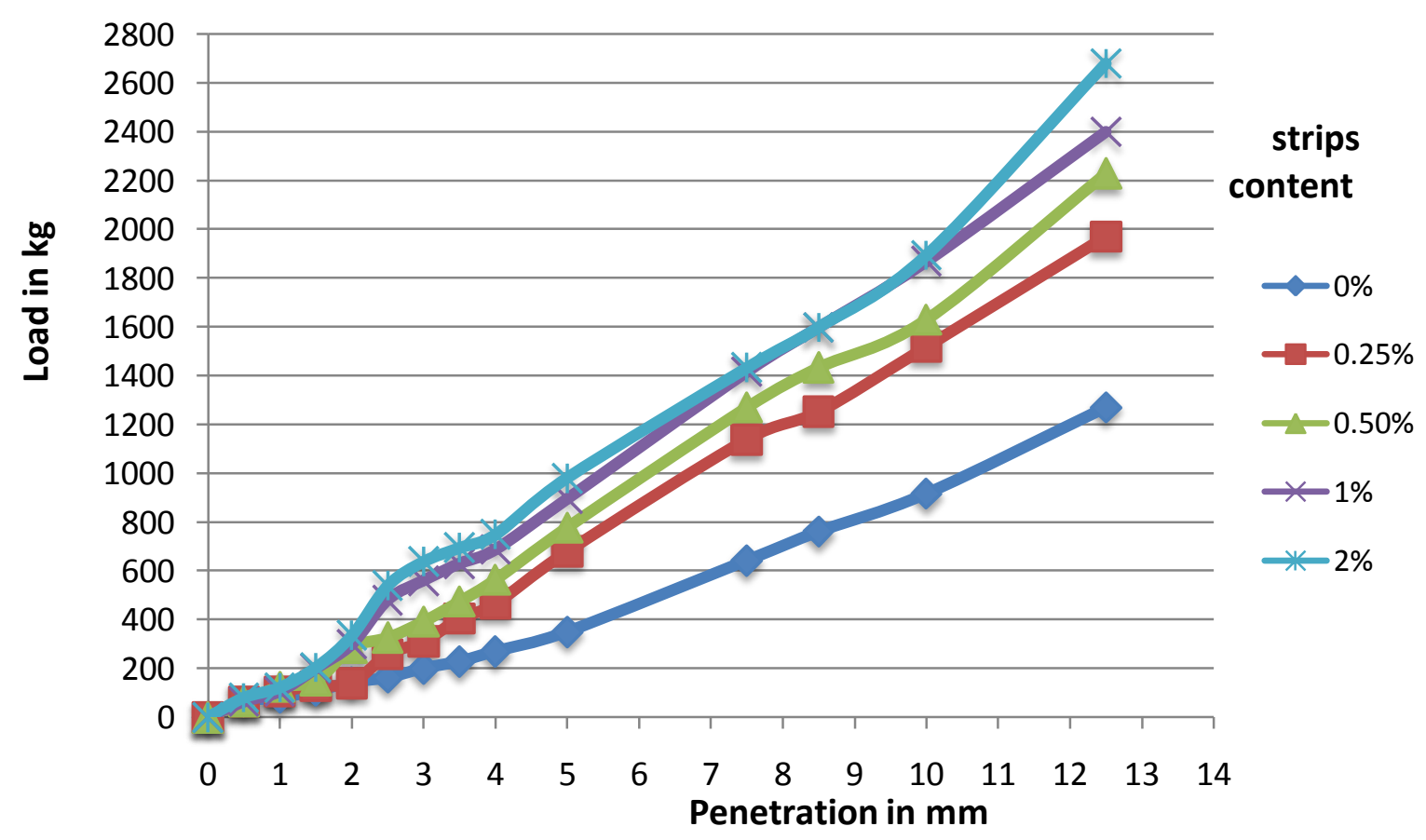

Fig-8 Load Penetration curve of stone dust with PET strips content ( $0.25 \%$ to $2 \%) \mathrm{AR}=3$ 


\section{CONCLUSION}

From the series of tests conducted on stone dust mixed with PET strips, the following conclusion are drawn

1. Maximum dry density of fiber mix stone dust increases with increase in fiber content. Optimum moisture content decreases with addition of plastic fibers.

2. Mixing of fiber can increase the strength of stone dust.

3. The addition of PET strips, a waste material, to stone dust increase the CBR value.

4. The reinforcement benefit increases with an increase in waste plastic strip content and length.

5. The maximum CBR value of reinforced system is approximately 2.79 times that of unreinforced system.

6 . This study is recommended to cost economics of the use of waste materials in base course in rural roads. Reinforced stone dust is more effective, it can be used as filling material in embankment construction over saturated clay.

\section{REFERENCES}

[1] Gray, D.H. \& Ohashi,H(1983) "Mechanics of Fiber reinforcement in sand" journal of Geotechnical Engg. ASCE, Vol.109, P.P 335-3512.

[2] Gray, D.H.\& Al-Refeai,T.(1986) “ Behavior of fabric versus fiber- reinforced sand" journal of Geotechnical Engg. ASCE, Vol-112, No-8, P.P 804820

[3] Maher, M.H. and Gray,D.H.(1990) " Static response of sand reinforced with randomly distributed fibers" journal of Geotechnical Engg., ASCE Vol- 116, P.P 1661-1677

[4] Maher,M.H. \& Ho,Y.C.(1994) “ Mechanical properties of kaolinite/ Fiber soil composite" journal of Geotechnical Engg., ASCE Vol- 120, P.P 13811393

[5] Dutta, R.K. and Sarda V.K. (2007) "CBR behavior of waste plastics strip reinforced stone dust/flyash overlying saturated clay" Turkish journal of engineering and environmental science, 31,(171-182)

[6] Rao, G.V. and dutta R.K. (2004) "Ground improvement with plastic waste International conference on ground improvement technique, Kaulalumpur, Malaysia (321-328)

[7] Dutta, R.K. Gayathri, V. and Sarda V.K. "A study of the CBR behavior of low density polyethylene waste plastic strip" Indian geotechnical conference 2009

[8] Choudhary A.K., Jha J.N. \& Gill K.S. (2010) “A study of CBR behavior of waste plastic strip reinforced soil " Emirates journal for engineering research 15(1), 51-57 (2010)

[9] Consoli,N.C.,Moutardo,J.P.,Prietto,P.D.M.,Pasa,G.S. (2002) "Engineering behavior of a sand reinforced with plastic waste ." journal of Geotechnical and Geoenvironmrntal Engg. ASCE, Vol-128(6) P.P 462472.

[10] Consoli,N.C.,Vendruscolo,,J.P.,Prietto,P.D.M.,Pasa, G.S.(2003) "Behavior of plate load tests on soil layers improved with cement \& fiber". Journal of Geotechnical and Geoenvironmental Engg.ASCE 129(1) P.P. 96-101
[11] Consoli, N.C., Moutardo, J.P.Donato, M.Prietto, P.D.M., Pasa, G.S.(2004) "Effect of material properties on the behavior of sand-cement-fiber composites ground improvement". Journal of Geotechnical and Geoenvironmental Engg. ASCE 8(2), P.P. 77-90

[12] IS: 2720(Part 2), 1973 Methods of Test for Soils, Determination of water content.

[13] IS:2720(III/SEC-I): 1980 Methods of Test for Soils, Determination of specific gravity.

[14] IS:2720(VII):1980 Methods of Test for Soils, Determination of water content dry density relation using light compaction.

[15] IS:2720(IV):1985 Methods of Test for Soils, determination of grain size analysis.

[16] IS:2720(Part 16), 1987 Methods of Test for Soils, Determination of California bearing ratio. 